\title{
MOŽNOSTI VYUŽITÍ ODPADNÍCH LÁTEK V SYSTÉMECH BEZVÝKOPOVÝCH RENOVACÍ POTRUBÍ
}

\author{
POSSIBILITIES OF USING WASTE MATERIALS IN TRENCHLESS \\ RENOVATION PIPING SYSTEMS
}

\author{
Jana Majerová, ${ }^{*}$, Rostislav Drochytka ${ }^{1}$, Radek Hermann ${ }^{1}$, Petr Figala ${ }^{1}$
}

"majerova.j@fce.vutbr.cz

${ }^{1}$ Vysoké učení technické v Brně, Fakulta stavební, Veveří 331/95, 60200 Brno

\begin{abstract}
Abstrakt
V systému bezvýkopových oprav potrubí metodou CIPP jsou klíčové vlastnosti pryskyřičného systému. Především plniva ovlivňují vlastnosti pryskyřičného systému i cenu renovace. To je ekonomicky významné v době, kdy roste cena primárních surovin. Jednou z ekologicky i ekonomicky atraktivních možností je využití druhotných surovin. Článek popisuje vlastnosti některých vhodných druhotných surovin a jejich vliv na vlastnosti pryskyřičného systému ve srovnání s tradičními plnivy. Hlavním cílem je dosažení ideálního poměru pojiva a alternativního plniva při zachování co nejlepších vlastností sanačního systému. V článku jsou srovnávány tři druhy druhotných odpadních materiálů a referenčního plniva. Důležitý je obsah $\mathrm{SiO}_{2}$, velikost částic plniva a mechanické parametry navržených receptur.
\end{abstract}

Klíčová slova

Plniva, druhotné suroviny, bezvýkopová renovace, pryskyřičný systém

\begin{abstract}
Properties of the resin system are key properties in the CIPP trenchless pipeline repair system. Fillers affect the properties of the resin system and the cost of renovation. One of the ecologically and economically attractive options is the use of secondary raw materials. The article describes the properties of some suitable secondary raw materials and their influence on the properties of the resin system in comparison with traditional fillers The article compares three types of secondary waste materials and the reference filler. The $\mathrm{SiO}_{2}$ content, the particle size of the filler and the mechanical parameters of the proposed recipes are most important.
\end{abstract}

\section{Key words}

Fillers, secondary raw materials, trenchless renovation, resin system

\section{1 ÚVOD}

Stále rostoucí cena a vyčerpatelné zdroje vstupních surovin pro výrobu stavebních materiálů vede k spolupráci výrobců stavebních materiálů s výzkumnými centry a univerzitami. Předmětem spolupráce může být i začlenění a využití odpadních látek jako druhotných surovin ve výrobě. Důraz je především kladen na ekologií a ochranu životného prostředí a planety. To je cílem i této práce.

Autoři si na začátku položili otázku, jestli je možné nahradit alespoň část primárního plniva v pryskyřičném systému pro bezvýkopové renovace potrubí metodou CIPP. Dalším bodem je zkoumání optimálního množství náhrady primárního plniva při dosažení co nejlepších mechanických vlastností.

Snaha je najít plnivo, které je svým chemickým a granulometrickým složením co nejvíce podobné běžně používaným surovinám, které budou v experimentu sloužit jako reference. Vycházet se bude z literárního přehledu dané problematiky. Celkově je však oblast bezvýkopových renovací potrubí spíše otázkou praxe a akademických prací a odborných publikací na danou problematiku existuje poskrovnu. 


\section{LITERÁRNÍ PŘEHLED/POPIS SOUČASNÉHO STAVU}

Mechanické a chemické vlastnosti kompozitu jsou zásadní pro konečné vlastnosti produktů CIPP (Cured In Place Pipes). Ty jsou zajištěny především výběrem složením pryskyřičného systému. Pryskyřičný systém se skládá z pojiva (pryskyřice), plniva a dalších přísad upravujících vlastnosti čerstvé nebo vytvrzené hmoty (zpracovatelnost, tepelná odolnost, ...) [1].

Běžně používaná plniva jsou vápenec, mastek a velmi jemný křemenný písek nebo křemennáá moučka [2]. V studii se Allouche a kol. [3] zaměřili na kompozity, ve kterých byly jako plniva použity mastek a trihydrát oxidu hlinitého (retardant hoření). Zpětnou analýzou neznámých vzorků z realizací bylo zjištěno, že kompozit obsahuje $12 \%$ plniva. Př́idavek plniva zlepšuje mechanické vlastnosti kompozitu a snižuje náklady. Zástupci instalačních firem zároveň vypozorovali, že použitý uhličitan vápenatý může časem reagovat s odpadními plyny a produkty v potrubí, což vede k oslabení celého potrubí [4]. Ideální je tedy volit inertní plniva, která nereagují s pryskyřicí ani s prostředím v potrubí). Použití plniv má pozitivní vliv i na smrštění pryskyřice po vytvrzení [5], [6]. Díky tomu je přilnutí nového potrubí k hostitelskému těsnější, a tedy je předpoklad pro delší životnost kompozitu a celé renovace. $V$ praxi se v některých př́ípadech používá až $25 \%$ plniva.

Měrná hmotnost plniva musí být vyšší než měrná hmotnost pojivového základu (pryskyřice), ne však výrazně vyšší. Ku př́ikladu, když je měrná hmotnost pojivového základu (pryskyřice), pro které je plnivo určeno, je cca 1,0 1,2 $\mathrm{g} \cdot \mathrm{cm}^{-3}$, je nezbytné, aby plnivo nemělo měrnou hmotnost menší než $1,3 \mathrm{~g} \cdot \mathrm{cm}^{-3}$. Pokud by měrná hmotnost plniva klesla pod $1,3 \mathrm{~g} \cdot \mathrm{cm}^{-3}$, došlo by k segregaci plniva a vyplavení na povrch pojivové báze, což je absolutně nežádoucí [7].

\section{METODIKA}

V úvodní fázi experimentu byl sestaven soubor potenciálních plniv, kterých vlastnosti byly později zkoumány a srovnány. Jako reference byla použitá křemenná moučka. Jako druhotné suroviny byly zvoleny odpadní pěnové sklo, odpadní borosilikátové sklo a dinasový zlom.

\section{Pojivo}

Nejvíce používanými pojivy pro metodu CIPP jsou polyesterové a epoxidové pryskyřice, dále je možné použití vinylesterových nebo epoxyvinyl esterových pryskyřic. Pro účely experimentu byla zvolena polyesterová pryskyřice. V praxi je využívaná zejména dobré chemické odolnosti, která je vhodná do kanalizačního prostředí a dobré finanční dostupnosti. Mezi nejdůležitější, sledované parametry používaných pojiv patři chemická odolnost, odolnost proti mechanickému obrusu, adhezní vlastnosti a schopnost penetrace do struktury použitého rukávce.

\section{PIniva}

Křemenná moučka byla jako referenční plnivo zvolena na základě zkušeností z praxe. Je to v podstatě velmi jemně namletý čistý křemenný písek, tedy obsah $\mathrm{SiO}_{2}$ se blíží ke $100 \%$ a velikost částic je menší než $0,063 \mathrm{~mm}$.

Odpadní pěnové sklo je vedlejším produktem při výrobě pěnového skla firmy Refaglass s.r.o Vintířov. Pěnové sklo se ve velké míre používá jako izolační materiál. Frakce s velikostí pod $4 \mathrm{~mm}$ jsou pro společnost nepoužitelné a stávají se odpadem. Odpadní pěnové sklo se vyznačuje velmi vysokým obsahem $\mathrm{SiO}_{2}$. Díky tomu je chemicky odolné a velmi vhodné pro účely experimentu.

Odpadní borosilikátové sklo typu SIMAX se vyznačuje vysokou chemickou a tepelnou odolností. Vyrábí se z něj chemické nebo varné nádobí odolávající vysokým teplotám. Kuličky z borosilikátového skla našli své využití ve výrobě kosmetiky, ve farmaceutickém průmyslu nebo v potravinářství.

Dinasový zlom je odpadní frakce ve výrobě dinasu. Část odpadu se vrací zpátky do výrobního procesu. I to však má své limity a omezení, proto se hledá další využití této suroviny. Obsah $\mathrm{SiO}_{2}$ je i v tomto př́ípadě vyšší než $93 \%$, proto byl materiál zařazen do experimentu.

\section{Zkoušky}

Po výběre vhodných druhotných plniv následovala úprava. Všechny suroviny byly pomleté v laboratorním mlýnu a přesátý přes síto s velikostí otvoru $0,063 \mathrm{~mm}$. Pro další zkoušky byly použity částice s velikostí pod $0,063 \mathrm{~mm}$. 
Velikost částic plniv byla analyzována pomocí laserového granulometru Malvern Mastersizer. Přístroj je určen pro měření velikosti částic stavebních materiálů, umožňuje vizualizaci disperze a aglomerace. Je schopen měřená částic od $0,001 \mathrm{~mm}$ až do $2 \mathrm{~mm}$. Výstupem zkoušky byly podklady pro sestavení křivek zrnitosti.

Dále byly navrženy receptury s obsahem plniva $10 \%, 15 \%$ a $20 \%$. Pro ověření mechanických vlastností byly dle navržených receptur vyrobena zkušební tělesa. Vystýlka z netkaných polyesterových vláken byla nasycena pryskyřičným systémem a vytvrzena v laboratoři za zvýšené teploty a tlaku (Obr. 1).

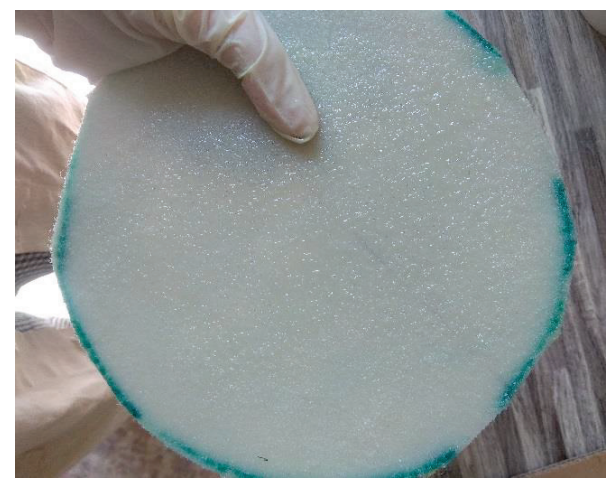

Obr. 1 Vystýlka z netkaných polyesterových vláken nasycená pryskyřičným systémem.

Řezáním na pile s diamantovým kotoučem byly připravená jednotlivá zkušební tělesa. Mechanické vlastnosti byly stanoveny na základě tříbodové ohybové zkoušky. Zkušební tělesa byla zatěžována v lisu Testometric M350 - 20CT rychlostí $10 \mathrm{~mm} / \mathrm{min}$ do prvního porušení (Obr. 2). Zatěžování odpovídalo zkušebnímu postupu definovanému v normě ČSN EN ISO 11296-4. Z grafického záznamu a výpočtu byly stanoveny hodnoty napětí ohybu při prvním porušení $\sigma_{\mathrm{fb}}$, krátkodobý modul pružnosti v ohybu a deformace ohybem při prvním porušení $\varepsilon_{\mathrm{fb}}$. Grafické zpracování výsledků je uvedeno v následující kapitole.
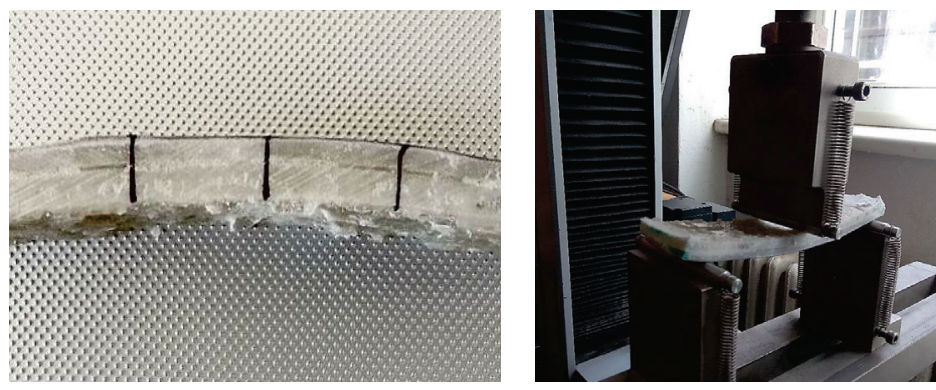

Obr. 2 Detail zkušebního tělesa (vlevo) a zkušební těleso při mechanických zkouškách (vpravo).

\section{VÝSLEDKY}

Na základě analýzy velikosti částic plniva byly sestaveny křivky zrnitosti pro každé plnivo, které jsou zobrazeny v souhrnném obrázku jako kumulativní křivky zrnitosti (Obr. 3). Mechanické vlastnosti byly vypočteny a zobrazeny v souhrnných grafech. Pro každou měřenou veličinu byl sestaven samostatný graf, ve kterém jsou mezi sebou srovnávány receptury podle obsahu plniva. Pro lepší přehled byla každému plnivu přidělena odlišná barva. První graf charakterizuje základní parametr, podle kterého se posuzuje kvalita kompozitu, kterým je krátkodobý modul pružnosti v ohybu $\mathrm{E}_{0}$.(Obr. 4). Následující grafy zobrazují další důležité vlastnosti, a to napětí v ohybu při prvním porušení $\sigma_{\mathrm{fb}}\left(\right.$ Obr. 5) a deformaci ohybem při prvním porušení $\varepsilon_{\mathrm{fb}}($ Obr. 6). 


\section{Velikost částic plniva}

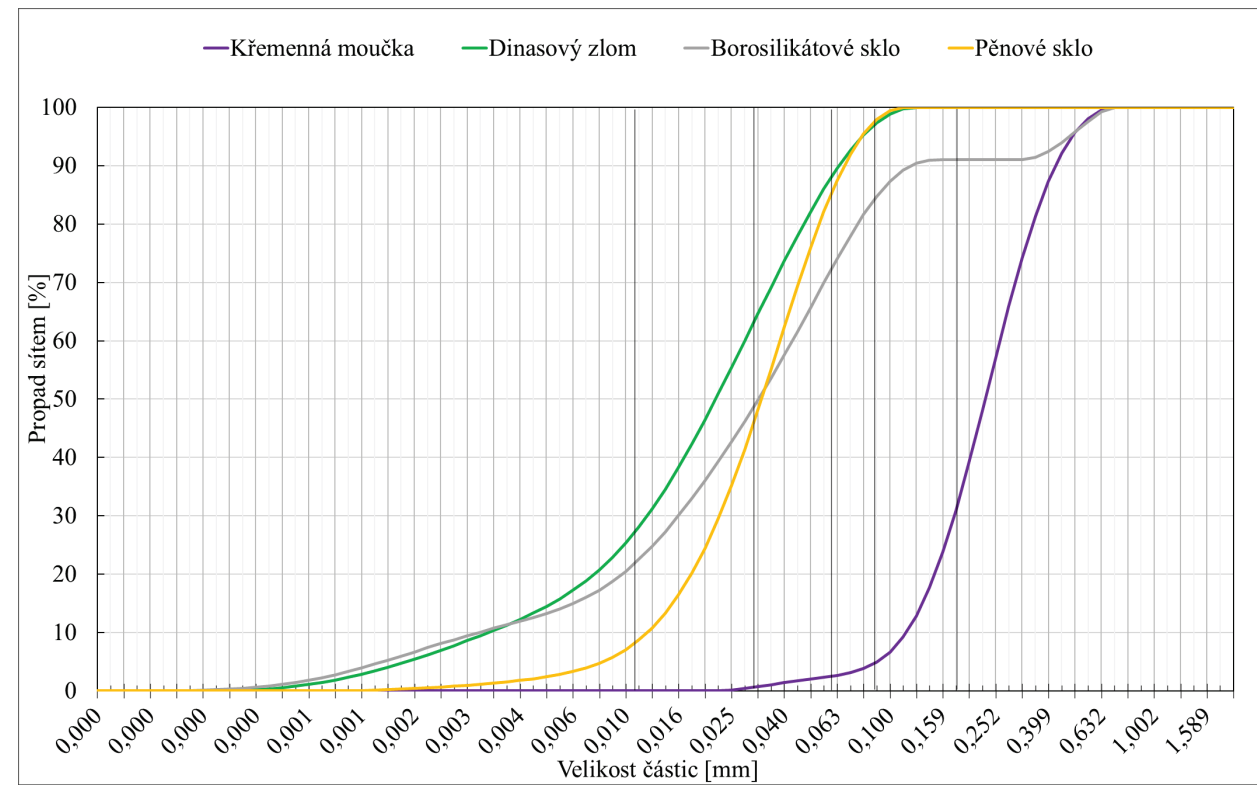

Obr. 3 Křivky zrnitosti testovaných plniv.

\section{Mechanické vlastnosti}

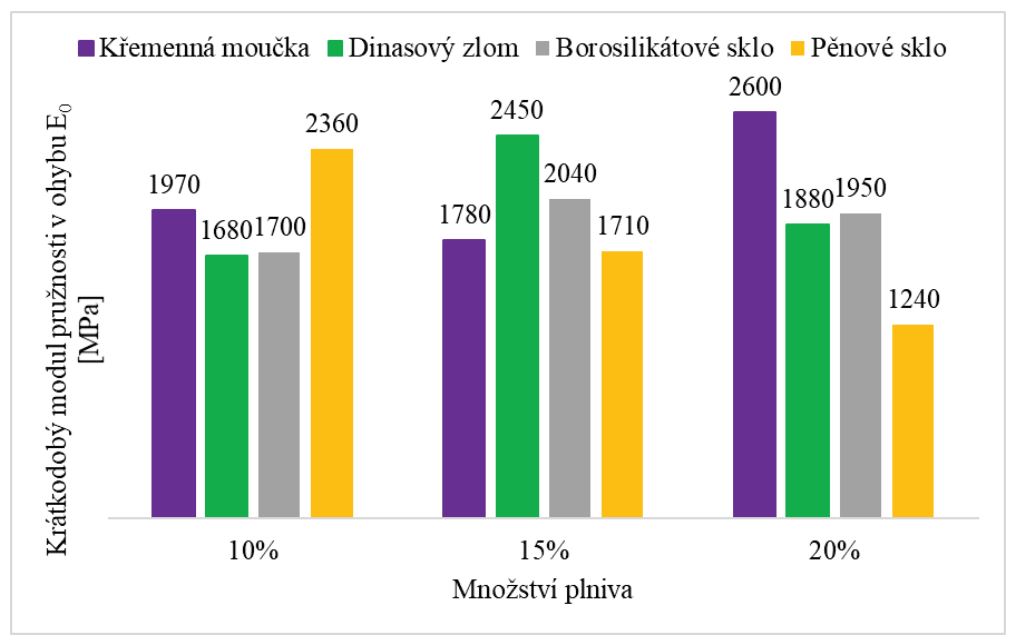

Obr. 4 Závislost hodnoty krátkodobého modulu pružnosti v ohybu na množství plniva. 


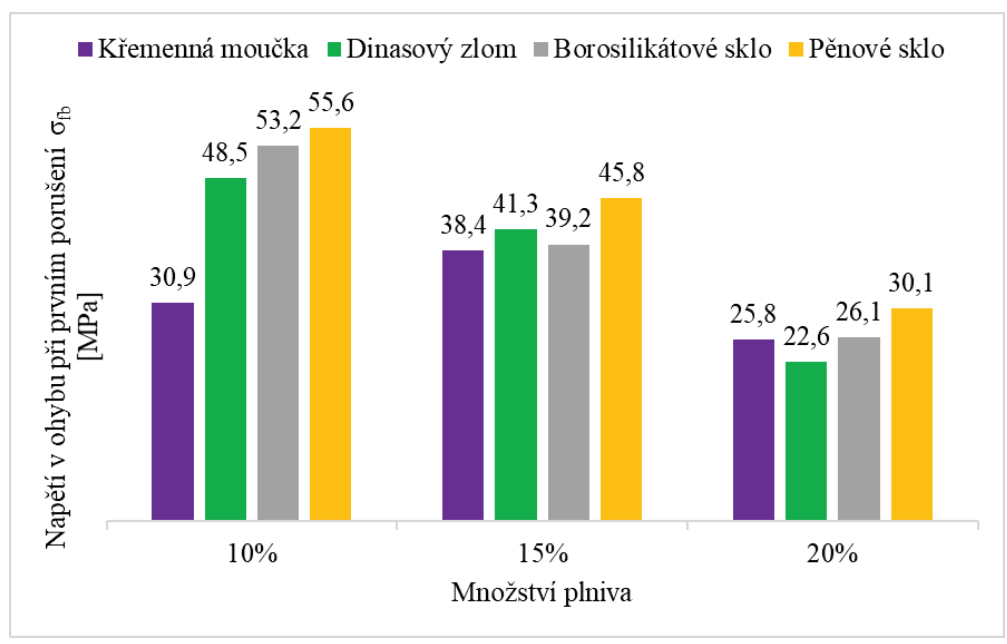

Obr. 5 Závislost napětí v ohybu při prvním porušení na množství plniva.

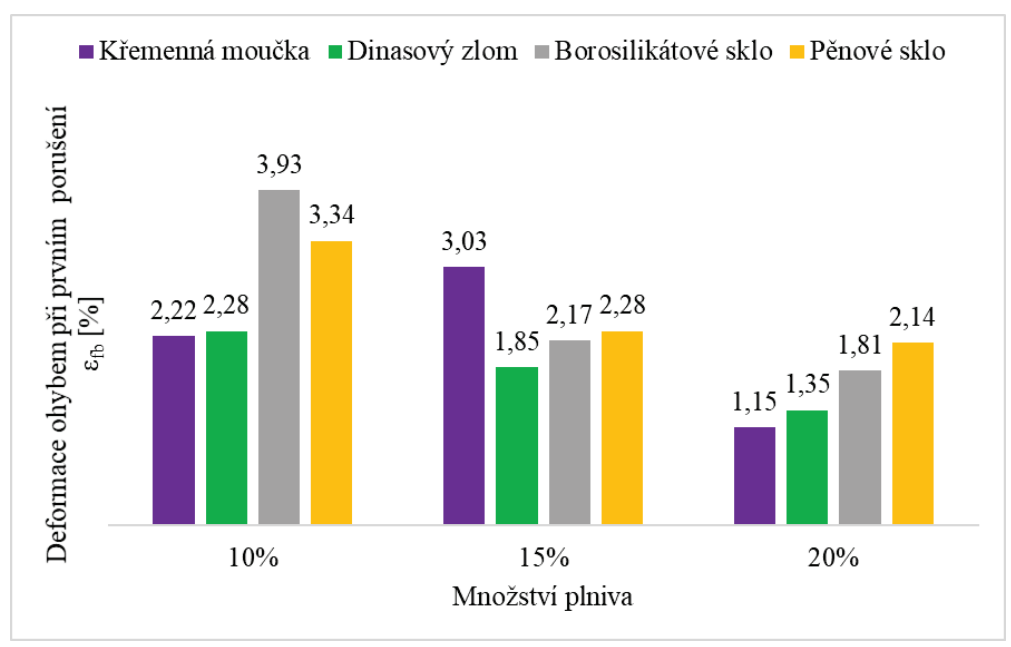

Obr. 6 Závislost deformace ohybem při prvním porušení na množství plniva.

\section{DISKUZE}

Na základě výsledků na samotných surovinách vyplývá, že všechny zvolené druhotné materiály z odpadních surovin jsou jemnější než primární plnivo, kterým byla křemenná moučka. Co se týče tvaru křivky zrnitosti, nejvíce podobný referenčnímu plnivu byl dinasový zlom. Křivka zrnitosti borosilikátového skla byla výrazně odlišná od ostatních křivek. Rozdíl spočíval v malém obsahu částic velikosti od 0,126 po 0,317 mm (Obr. 3).

$\mathrm{Na}$ základě ověření mechanických vlastností lze říct, že nejlepších mechanických vlastností dosahovaly zkušební vzorky s obsahem 20 \% referenčního plniva. U pěnového skla lze pozorovat, že se zvyšujícím množstvím plniva klesají mechanické vlastnosti zkušebních vzorků jako krátkodobý modul pružnosti v ohybu (Obr. 4) a rovněž i hodnoty napětí v ohybu při prvním porušení (Obr. 5) a deformace ohybem při prvním porušení (Obr. 6). Dinasový zlom v množství 15 \% dosahoval výrazně vyšších hodnot krátkodobého modulu pružnosti v ohybu jako v ostatních př́ípadech. Vzorky s plnivem z borosilikátového skla se vyznačovaly relativně konzistentními výsledky mechanických parametrů bez ohledu na množství použitého plniva.

V př́ípadě alternativních druhotných surovin se jeví $15 \%$ plnění jako optimální pro dosažení nejlepších mechanických vlastností. 


\section{ZÁVĚR}

Cílem experimentu bylo ověření možnosti využití druhotných surovin jako plniv v systému bezvýkopové renovace potrubí metodou CIPP. V úvodu byla položena otázka, zda je možné začlenit druhotné odpadní suroviny do pryskyřičného systému. Jako referenční plnivo byla zvolena běžně používaná křemenná moučka, která je tvořena téměř čistým $\mathrm{SiO}_{2}$. Všechna další plniva byla volena s co nejvyšším obsahem $\mathrm{SiO}_{2}$, co zajistí, že plnivo nebude reagovat s pryskyřicí a zajistí kompozitu dostatečnou chemickou a tepelnou odolnost.

Z provedených experimentů a jejich výsledků vyplývá, že je možné nahradit primární plniva druhotnými odpadními surovinami. V snaze najít nejvhodnější možné plnivo byly vzorky podrobeny analýze velikosti částic. Ta ukázala, že nejvíce podobným plnivem z hlediska granulometrie je dinasový zlom. To bylo dále ověřeno mechanickými zkouškami tř́ receptur, které se lišily množstvím plniva. Tady nebyly výsledky tak jednoznačné a prakticky pro každé plnivo existuje odlišné optimální množství plniva. $\mathrm{V}$ př́padě plniva z odpadního pěnového skla se so zvyšujícím množstvím plniva snižovali mechanické parametry.

Ze zkoumaných druhotných odpadních plniv se jako optimální jeví použití odpadního borosilikátového skla.

Závěrem lze ř́íct, že pomocí experimentu byly zodpovězeny otázky kladené v úvodu práce a určitě je vhodné dále se zabývat danou problematikou, zkoumat další možnosti použití a kombinace druhotných surovin.

\section{Poděkování}

Př́spěvek vznikl v rámci projektu FAST-J-21-7379 - Možnosti využití alternativních surovin jako plniva polymerních kompozitů pro bezvýkopové renovace potrubí.

\section{Použité zdroje}

[1] PUKÁNSZKY, B., Mineral-filled Polymers. Encyclopedia of Materials: Science and Technology, 2001, pp.5680-5683. doi:10.1016/b0-08-043152-6/00989x

[2] XANTHOS, Mario. Functional Fillers for Plastics. ISBN 3-527-31054-1.

[3] ALLOUCHE, E., S. ALAM, J. SIMICEVIC, R. STERLING, W. CONDIT, J. MATTHEWS a A. SELVAKUMAR. A pilot study for retrospective evaluation of cured-in-place pipe (CIPP) rehabilitation of municipal gravity sewers. Tunnelling and Underground Space Technology. 2014, 39, 82-93. ISSN 08867798. Dostupné z: doi:10.1016/j.tust.2012.02.002

[4] How Additives Affect CIPP Resins. Cleaner [online]. [cit. 2021-12-01]. Dostupné z: https://www.cleaner.com/online_exclusives/2019/11/how-additives-affect-cipp-resins

[5] MOORE, W.; DIG, NASTT-No. Non-styrene options for cured in place pipe. NASTT, No Dig February, 2011.

[6] ENGINEERING DESIGN GUIDE FOR REHABILITATION WITH CURED-IN-PLACE PIPE [online]. 2010 [cit. 2021-12-01]. Dostupné z: https://www.lanzo.net/pdf/lanzo-lining-guide-2410.pdf

[7] WYPYCH, George. FILLERS IN COMMERCIAL POLYMERS. Handbook of Fillers. Elsevier, 2016, 2016, , 665-761. ISBN 9781895198911. Dostupné z: doi:10.1016/B978-1-895198-91-1.50017-8 